\title{
Kütahya Yoncalı Kaplıca Bölgesi Peyzaj Tasarımına Yönelik Öneriler
}

\author{
Rumeysa KANBER ${ }^{(D)}{ }^{*}$, Mehmet TOPAY ${ }^{(D)} 2$ \\ ${ }^{1}$ Süleyman Demirel Üniversitesi, Fen Bilimleri Enstitüsü, Isparta \\ 2 Süleyman Demirel Üniversitesi, Mimarlık Fakültesi, Isparta \\ Geliş Tarihi (Received): 17.02.2021, Kabul Tarihi (Accepted): 31.03.2021 \\ $\square$ Sorumlu Yazar (Corresponding author*): rumeysakanber43@gmail.com \\ (C) +902462113978 杬 +902462118231
}

$\overline{O ̈ Z}$

Bu çalışmanın amacı; Kütahya Yoncalı Kaplıca Bölgesi peyzaj düzenlemesinin iyileştirilmesi amacıyla önerilerin geliştirilmesidir. Öncelikle bölgenin mevcut durumu incelenmiş, gelen ziyaretçi ve işletme sahipleri ile yüz yüze anket çalışmaları yapılmıştır. Anket soruları; ziyaretçiler için 13, işletme sahipleri için 11 sorudan oluşmuştur. Yapılan anketler sonucunda; ziyaretçilerin \%12,7'sinin yürüyüş yollarının alanda rahatça hareket imkanı sağlamadığı, \%26,7'sinin alanı çocuklar açısından yeterli derecede güvenilir bulmadığı, \%30'unun otopark ihtiyacının yeterli düzeyde karşılanmadığı görüşünde olduğu belirlenmiştir. Anket sonuçlarına göre; termal tesislere gelen ziyaretçilerin tesisleri seçiminde çevre düzenlemesine dikkat ettiği, çevre düzenlemesi yapılan tesislerin daha çok tercih edildiği anlaşılmıştır. Çalışmada belirlenen sorunların çözümüne yönelik öneriler geliştirilmiştir.

Anahtar Kelimeler: Kaplıca, Kütahya, peyzaj tasarımı, Yoncalı kaplıca bölgesi

\section{Suggestions for Landscape Design of Kütahya Yoncalı Thermal Region}

\section{ABSTRACT}

The aim of this study is to develop suggestions for improving the landscape of Kütahya Yoncalı Thermal Region. First of all, the existing condition of the region was examined; face-to-face questionnaire were conducted with incoming visitors and business owners. Questionnaire consisted of 13 questions for visitors and 11 questions for business owners. As a result of the questionnaire; it has been determined that $12.7 \%$ of the visitors think that the walking paths do not allow easy movement in the area, $26.7 \%$ of the visitors do not find the area reliable enough for children, and $30 \%$ of them think that the need for parking is not met at a sufficient level. According to the results, it has been understood that visitors coming to thermal facilities pay attention to landscaping in their selection of facilities, and that the facilities with landscaping are more preferred. Suggestions for the solution of the problems identified in the study have been developed.

Keywords: Thermal spring, Kütahya, landscape design, Yoncalı thermal region

\section{Gíriş}

Kaplıca turizm olgusu, insanların günlük hayattan uzaklaşarak kendilerine vakit ayırma, sağlık sorunları için tedavi yolları bulma, aktivite intiyaçlarını karşılama, yeni insanlar tanıyarak sosyalleşmeyi arttırma, yeni aktivitelere merak duygusu, kentin sorunlarından sıyrılıp doğayla baş başa kalarak huzur arama arayışı ve intiyacı sonucu oluşmuştur.
Kaplıca turizmi aslında sağlık bulmak amacıyla yapılan sağlık turizminin bir biçimidir (Kök, 2013; Deniz, 2016; Vural, 2019). Termal sular, içerisindeki yararlı bileşimler ve mineralli tuzlar sayesinde birçok hastalığa şifa bulmada bir aracıdır. Termal sular ile birçok tedavi yöntemleri uygulanmaktadır. Bunlardan başlıcaları; inhalasyon, çamur banyosu, psikoterapi, fizik tedavi ve rehabilitasyon yöntemidir. 
Kaplıca turizmi kapsamında önemli unsurlar olan termal tesislerin planlama ve tasarımının iyi yapılması (kaplıca, kür merkezi vb.) uygulanan tedavilere destek olabilmesi açısından büyük bir önem arz etmektedir (Topay ve Küçük, 2010).

\section{Kaplıca Turizminde Planlama ve Tasarım}

Türkiye'de jeotermal kaynakların kullanımında daha verimli ve etkili bir anlayışla, geleneksel termalden farklı bir yaklaşım geliştirmeye çalışılmaktadır. Termal turizmin gelişmesi için kür parkı, kür merkezi ve konaklama entegrasyon tesislerini içeren uluslararası standartlara sahip nitelikli tesis sayısı ile birlikte turizm gelirinin ve turist sayısının artırıması hedeflenmektedir. $\mathrm{Bu}$ amaçla, termal alanların koruma ve kullanım dengesiyle öncelikli olarak planlanması amaçlanmaktadır (Topay ve Küçük, 2010; Deniz, 2016).

Kaplıca turizmi, ülkemizde gün geçtikçe önem kazanmaya başlamış ve bununla birlikte termal tesis sayısında da artış yaşanmaya başlanmıştır. Bu artışın devamlılığını sağlayabilmek için, tesislerde ve yakın çevresinde yapılacak peyzaj tasarım çalışmalarının işlevine uygun yapılması büyük önem arz etmektedir.
Peyzaj tasarımı iyi yapılmış bir tesis, ziyaretçiler açısından olumlu etkileri olmaktadır (Topay ve Küçük, 2010; Uzun ve ark., 2013). Yapılan araştırmalar, kürden sonra insanların intiyaçları doğrultusunda iyi bir şekilde tasarlanmış bir çevrede olmanın, psikolojik açıdan olumlu etkileri olduğunu ifade etmektedir (Topay ve Küçük, 2010).

\section{MATERYAL VE YÖNTEM}

\section{Materyal}

Çalışmanın ana materyalini Kütahya'da bulunan Yoncalı Kaplıca Bölgesi oluşturmaktadır. Ayrıca, kaplıca alanına gelen ziyaretçilere ve işletme sahiplerine bir anket uygulanmıştır.

\section{Çalışma Alanının Genel Özellikleri}

\section{Coğrafi Konum}

Yoncalı Kaplıca Bölgesi, Kütahya ilinin batısında 16 km uzaklıkta yer almaktadır. Rakımı 1000-1025 m arasındadır (Şekil 1).

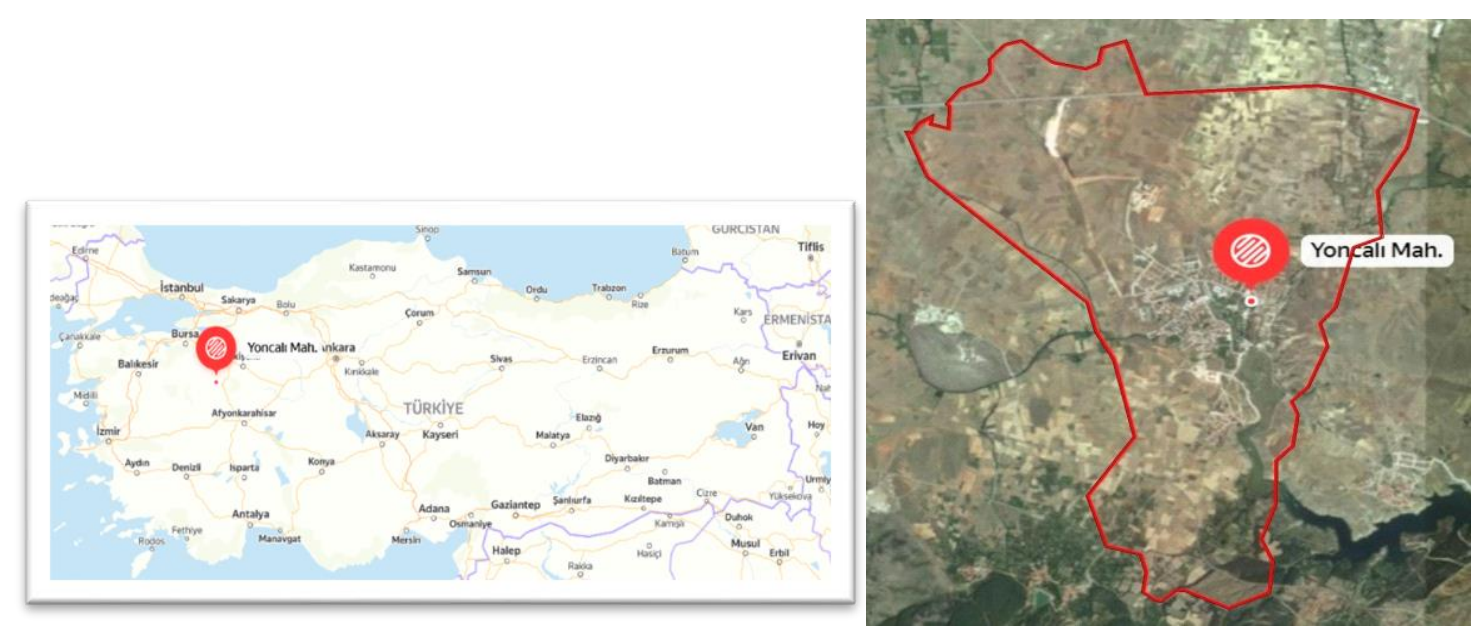

Şekil 1. Yoncalı Kaplıca Bölgesi'nin Türkiye içindeki konumu (Yandex, 2020)

\section{İklimsel Veriler}

Aşağıda Şekil 2'de gösterildiği üzere Yoncalı iklim grafiklerine ait bilgiler yer almaktadır. Ortalama en yüksek sıcaklık Temmuz ayında $19,7^{\circ} \mathrm{C}$, en düşük sıcaklık ise Ocak ayında $0^{\circ} \mathrm{C}$ olduğu, ortalama en az yağış miktarı, Ağustos ayında $13 \mathrm{~mm}$, en yüksek $94 \mathrm{~mm}$ ile Aralık ayında olduğu bilgisi yer almaktadır. (Climate-Data, 2019).

\section{Jeomorfoloji}

Yoncalı Kaplıcaları Köprüören Ovası içinde yer alır. Yoncalı Kaplıca Bölgesinde güneye doğru gidildikçe yükseklik artmaya başlar. Yoncalı Kaplıcaları'nın güneyinde Kirazıı Dağı ve Yellice Dağı bulunmaktadır. Çalışma alanının eğim durumu \%0-10 ve \%10-20 arasındadır (Şekil 2) (Haşimoğlu, 2007). 


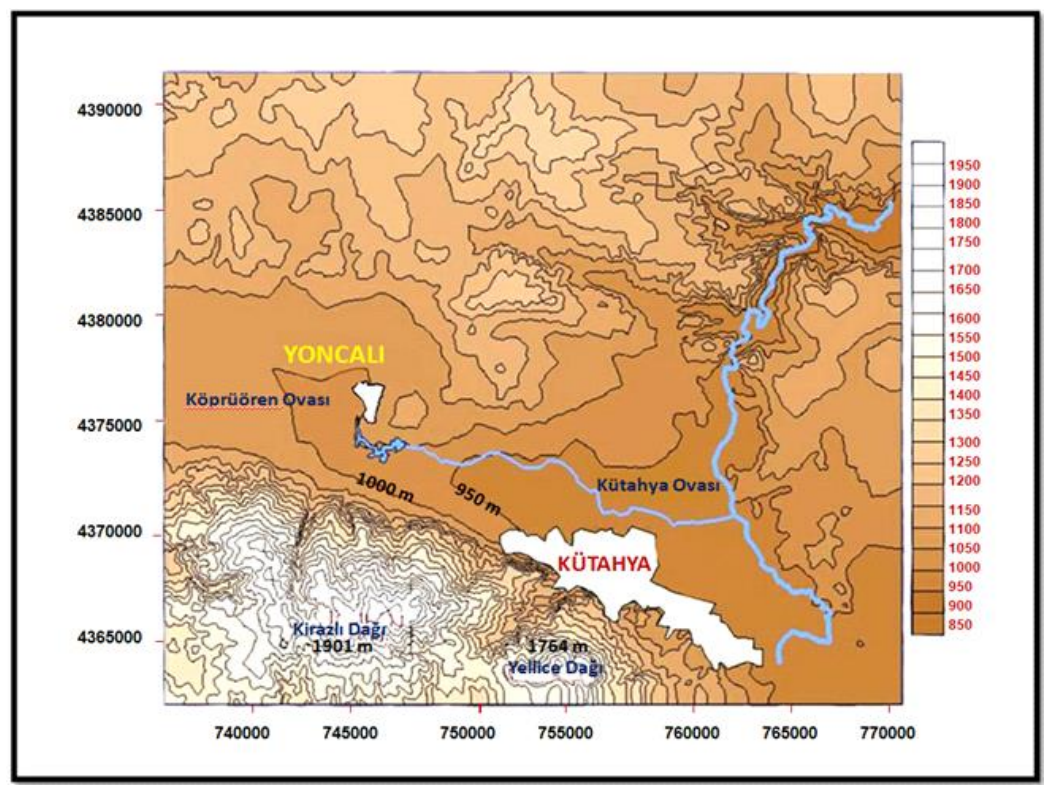

Şekil 2. Yoncalı Kaplıca alanı ve yakın çevresinin yükselti haritası

\section{Hidrolojik Yapı}

Yoncalı Kaplıca alanında bulunan 10-40 m kalınlığında bulunan alüvyonlar ve kristalize kireçtaşları bir akifer oluşturmaktadır. Alanda su seviyeleri yaz aylarında 3-5 m, kış aylarında 1-3 m'dir. Yoncalı Kaplıcaları'nın suları Dübecikler, Eskideğirmen, Hamam, Otel ve Valikonağı yönünde yükselir. Yapılan analiz sonuçlarında, Yoncalı Kaplıca sularının bikarbonatlı, sülfatlı, kalsiyumlu ve magnezyumlu oldupu görülmüştür (Haşimoğlu, 2007).

\section{Doğal Bitki Varlığı}

Yoncalı Kaplıcaları'nda bitki örtüsü olarak step hakimdir. Kültür ve Tabiat Varlıklarını Koruma Yüksek Kurulu'nun 658 sayılı arkeolojik sit alanları hakkındaki ilke kararında, "I. derece arkeolojik sit alanlarında hiçbir şekilde yeni ağaç dikimi ya da tarımsal alanların açımasına izin verilmemektedir" (Haşimoğlu, 2007). Kaplıca alanında kaynak koruma zonu kapsamına giren bölgelerdeki bitkilendirmeler, koruma zonu derecelerine göre belirlenen kurallar çerçevesinde ve kurul kararı ile yapılmalıdır.

\section{Yöntem}

Çalışma kapsamında, kullanıcılara yönelik yapılacak anket formu örnekleri incelenmiş ve uzman görüşlerinden yararlanılarak bir anket formu oluşturulmuştur. Hazırlanan anket formu, çalışma alanına gelen ziyaretçilere ve çalışma alanında bulunan işletme sahiplerine uygulanmıştır. Anketler, Kütahya ili Yoncalı Kaplıcaları'nda bulunan işletme sahipleri ve bu işletmelere gelen 400 kişiye uygulanmıştır. Alana gelen ziyaretçi kapasitesinin işletmeci kapasitesinden fazla olması sebebi ile 300 anket ziyaretçiler ile 100 anket ise işletme sahipleri ile yapılmiştır.

Anket yapılacak denek sayısı, termal tesislerde 2019 yılında konaklayan yerli - yabancı kişi sayısı ve çalışma alanında bulunan işletme tesislerinin ortalama sayısı dikkate alınarak \%95 güven aralığında 385 kişi olarak belirlenmiştir (KTB, 2020). Fakat çalışmanın güvenirliliğini arttırmak için 400 kişi ile anket yapılmıştır. Örneklem büyüklüğünü bulmak için kullanılan formül (Denklem 1) aşağıdaki gibidir (Devecioğlu, 2015).

$$
n=\frac{N \cdot P \cdot Q \cdot Z_{a}{ }^{2}}{(N-1) \cdot d^{2}}
$$

N: Evren birim sayısı

n: Örneklem büyüklüğü

$P$ : Evrendeki X'in gözlenme oranı

$Q$ (1-P): X'in gözlenmeme oranı

$\mathrm{Z} \alpha$ : Güven katsayısı ( 0,05 güven için bu katsayı 1,96 olarak alınmıştır) $\mathrm{d}=$ Örneklem hatası (bu çalışma için \%5'lik örneklem hatası öngörülmüştür)

Anket soruları ziyaretçiler için 13 soru, işletme sahipleri için 11 sorudan oluşmaktadır. Ziyaretçilere uygulanan anket; demografik özellikler ile tesisi seçerken peyzaj tasarımının olmasına dikkat edilip/edilmediği, peyzaj tasarımının tesise ve ziyaretçilere olan maddi ve manevi etkilerinin nasıl olduğu gibi konularda ziyaretçilerin görüşlerini belirlemeye yönelik sorulardan oluşmaktadır (hazırlanan anket soruları kapsamında 5 soru demografik 
verilerden, 8 soru ise ziyaretçi görüşlerinden oluşmaktadır). İşletme sahiplerine uygulanan anket; demografik özellikler ile tesisin çevresindeki alanın olup/olmadığını, eğer varsa peyzaj tasarımının yapılıp/yapılmadığını, peyzaj tasarımının gerekli olup olmadığını belirlemeye yönelik sorulardan oluşmaktadır (hazırlanan anket soruları kapsamında 4 soru demografik verilerden, 7 soru ise işletme sahiplerinin görüşlerinden oluşmaktadır).

Anketlerin uygulaması tesadüfi seçilen kişiler ile yüz yüze görüşmeler halinde yapılmıştır. Anketler 2019 yılının Temmuz - Aralık ayları arasında yapılmıştır. Çalışma alanında yapılan anketlerden elde edilen sonuçlar "Statistical Package for the Social Sciences" (SPSS) programı ile bilgisayar ortamından faydalanılarak veri haline getirilmiştir. Daha sonra hazırlanan veriler yine aynı program ile değerlendirilmiştir.

Veri analizleri "x2 (ki-kare) testleri" ile oluşturulmuştur. X2 testi, iki ya da daha fazla değişken arasında anlamlı bir ilişki olup olmadığının tespit edilmesi yöntemidir. Gözlenen frekans değerleriyle elde edilen frekans değerleri arasında istatistiki açıdan bir fark olup olmadığı test edilmektedir. $\alpha=0.05$ olarak alındığında $p$ değeri, 0.05 'ten büyük ise istatistiki açıdan anlamlı bir ilişki bulunmamış, 0.05 'ten küçük ise istatistiki açıdan anlamlı bir ilişki bulunmuştur (Devecioğlu, 2015).

\section{BULGULAR VE TARTIŞMA}

\section{Ziyaretçilere Uygulanan Anket Verilerinin İncelen- mesi}

Ankete katılan ziyaretçilerin cinsiyet, yaş, eğitim, meslek, gelir durumlarına ait sorular bu başlık altında gösterilmiştir. Buna göre, ankete katılanların cinsiyet durumlarına bakıldığında; \%54'ü erkek, \%46'sı ise kadın olduğu görülmektedir. Ankete katılanların yaş aralıklarına bakıldığında; \%66'sı 18-65 yaş grubu arasında, \%23'ü 66-79 yaş grubu arasında, \%8'i 0-17 yaş grubu arasında ve \%3'ü 80 yaş ve üzeri yaş grubunda olduğu görülmektedir. Ankete katılanların eğitim durumlarına bakıldığında; \%47'si ön lisans mezunu, \%32'si ortaöğretim (lise) mezunu, \%11'i ilköğretim mezunu, \%7'si lisansüstü mezunu ve \%3'ü lisans mezunu olduğu görülmektedir. Ankete katılanların meslek durumlarına bakıldığında; \%22'sinin emekli, \%21'inin memur olduğu, $\% 16$ 'sının özel sektörde çalıştığı, \%13'ünün ev hanımı, $\% 9$ 'unun serbest meslek ve öğrenci olduğu, \%7'sinin kamu çalışanı ve \%3'ünün akademisyen olduğu görülmektedir. Ankete katılanların aylık gelir durumlarına bakıldığında; \%51'inin 3.996-12.375 TL arasında olduğu, \%25'inin 1026-3995 TL arasında olduğu, \%17'sinin 1025 TL altında olduğu ve \%7'sinin 12.375 TL üzerinde olduğu sonucuna ulaşılmıştır.
Anket çalışmasına katılan ziyaretçilerde, tesislerin cezbedici özelliklerinin sonuçlarına bakıldığında; \%39'u "Hepsi" seçeneğini seçerek bütün seçenekleri cezbedici bulduğu, \%35'i doğal özellikleri bulundurması ve şifa kaynağı olmasını, \%13'ü doğa ile iç içe olmasını, \%7'si ise tesis imkanlarının güzel ve yeterli olmasını, \%5'i özgürlük hissi vermesi ve stresi azaltmasını cezbedici bulduğu görülmektedir. \%1'i ise hiçbir seçeneği cezbedici bulmadığı görülmektedir. Termal tesislerin katılımcıları rahatsız eden özelliklerinin sonuçlarına bakıldığında; \%27'si alanın çocuklar açısından yeterli derecede güvenilir olmamasını, \%26'sı yeterli otopark intiyacını bulundurmamasını, \%18'i oturma bankları ve piknik masalarının yetersiz olmasını, \%17'si alanın peyzaj açısından yetersiz kalmasını ve \%12'si ise yürüyüş yollarının alanda rahatça hareket imkanı sağlamamasını rahatsız edici bulduğu görülmektedir. Termal tesisleri seçerken çevre düzenlemesinin dikkat edilip edilmemesinin sonuçlarına bakıldığında; ziyaretçilerin \%77'si eveti seçerek çevre düzenlemesine dikkat ettiği anlaşılmaktadır. Çevre düzenlemesi yapılan tesislerde işletmelere olumlu katkılar bırakıp bırakmadığının sonuçlarına bakıldığında; ziyaretçilerin \%80'i eveti seçerek çevre düzenlemesi yapılan tesislerin işletmelere maddi ve manevi katkılar sağladığı yönünde bilgilere ulaşılmıştır.

Kaplıca tesislerinin bulunduğu çevrenin düzenlemeleri büyük bir önem taşımaktadır. Anket çalışmalarında elde edilen sonuçlara göre tesislerin çevrelerinde yapılan düzenlemeler tesislerin tercih edilmesini yüksek oranda arttırmaktadır. Fakat plansız yapılan çalışmalar intiyaçları karşılayamamaktadır. Yapılan anket sonuçlarında görüldüğü üzere doğru sonuçlara ancak, alanında uzman peyzaj mimarları tarafından uygulanacak planlama ve tasarım çalışmalarının işlevine uygun olarak yapıldığı takdirde ulaşılabileceği görülmektedir. Fakat maliyetlerin yüksek olması nedeniyle genellikle düşük gelirli işletmeciler tarafından tercih edilememektedir.

Bu değerlendirmeler kapsamında peyzaj mimarları tarafından işlevine uygun yapılan peyzaj tasarımlarının işletmelerin ziyaretçi kapasitesini arttırabilmek ve ileriye dönük olumlu katkılarının oluşacağını göz ardı etmeden ideal tasarımların yapııması sağlanmalıdır. Ortaya çıkan yüksek maliyetler de, tesislerin tercih edilme oranlarında artış yaşanması ile kısa süre içerisinde telafi edilebilecektir (Topay ve Küçük, 2010).

Yapılan anket sonuçlarının değerlendirmesinde Yoncalı Kaplıca alanına girişte güvenli bir nokta sağlamak için alana giriş ve çıkış kontrolünün sağlanabileceği bir kontrol noktası bulunmamaktadır (Şekil 3). 


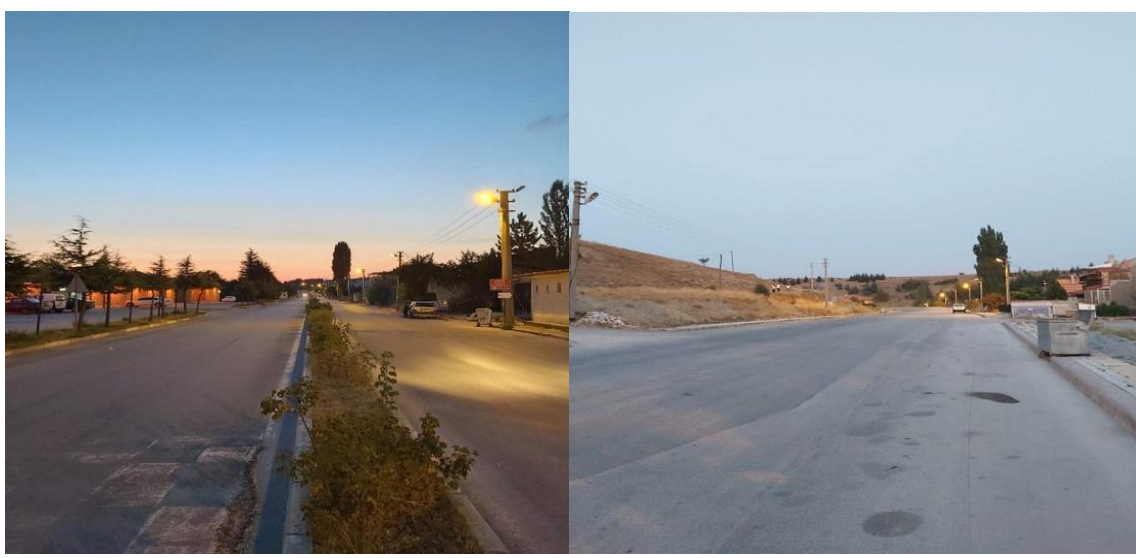

Şekil 3. Çalışma alanı girişi

Yapılan anketler sonucunda; ziyaretçilerin \%26,7'sinin, alanı çocuklar açısından yeterli derecede güvenilir bulmadığı sonucuna ulaşılmıştır. Alanda termal tesislere gelen ziyaretçi kapasitesinin ve güvenirliliğin arttırılması açısından girişte ve tarihi hamamın bulunduğu bölgede güvenli bir kontrol noktası (güvenlik, kamera sistemi vs.) oluşturulmalıdır.
Yapılan anketler sonucunda; ziyaretçilerin \%30'u otopark ihtiyacının yeterli düzeyde karşılanmadığı görüşünde bulunmuştur (Şekil 4).

Kapasite dışında kalan araçların kaldırım kenarlarına park ettiği görülmektedir (Şekil 5).

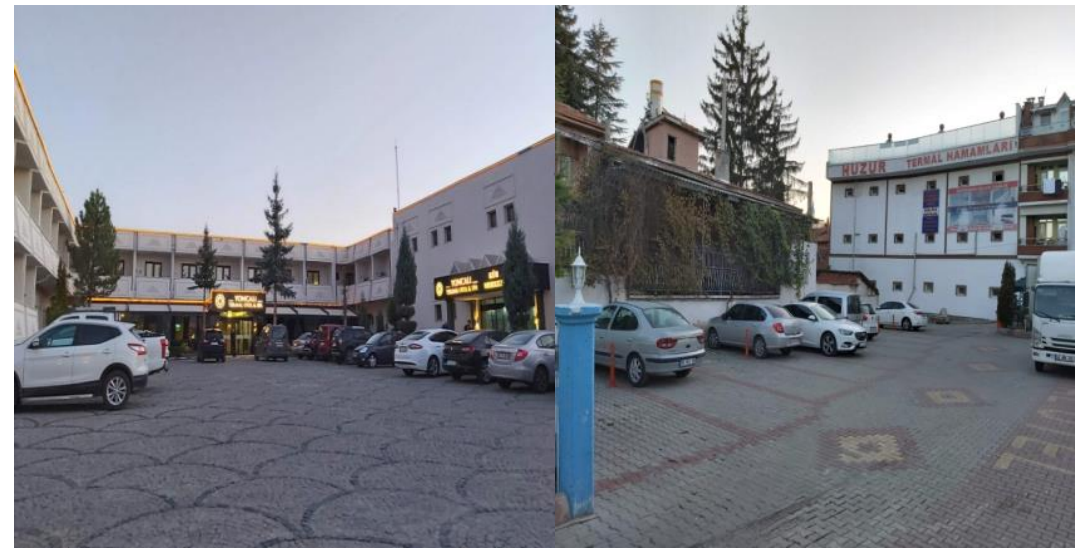

Şekil 4. Çalışma alanındaki termal işletmelerinin otopark alanları

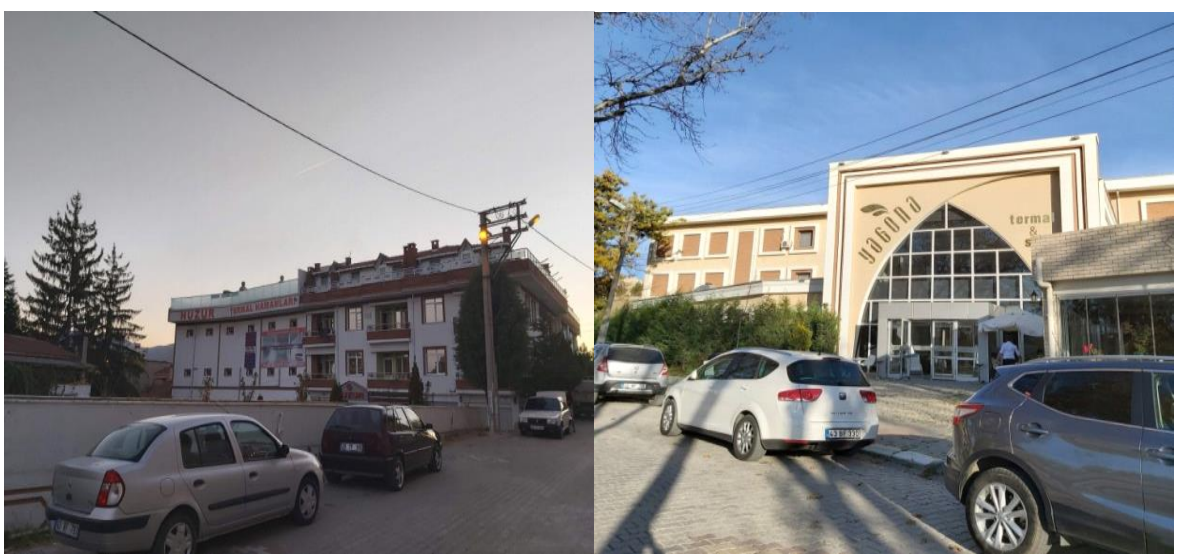

Şekil 5. Çalışma alanında kapasite dışı kaldırımlara park etmiş araçlar 
Kapasiteye göre otopark alanları arttırılmalıdır. Alanın bahçesinde yeterli bir alan mevcut değilse yakın bir alanda kapasiteye uygun düzeyde kullanım alanları tasarlanmalıdır.

Yapılan anketler sonucunda; ziyaretçilerin \%18'inin alanda oturma bankları ve piknik masalarını yetersiz düzeyde bulduğu görülmüştür (Şekil 6).
Kaplıca alanının çevresinde bulunan parklardaki oturma elemanları Şekil 7'de gösterilmektedir.

Alanda kentsel mobilya olarak belirli noktalarda (termal tesis, camii ve park alanları vb.) çöp kutuları bulunmaktadır (Şekil 8).

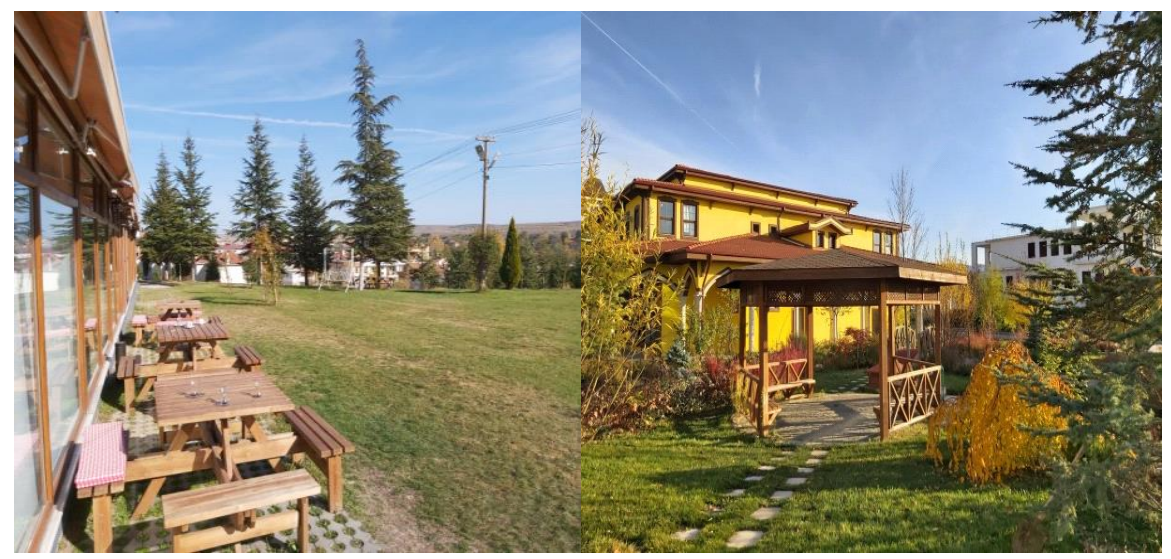

Şekil 6. Çalışma alanındaki termal işletmelerinin bahçesinde bulunan oturma elemanları

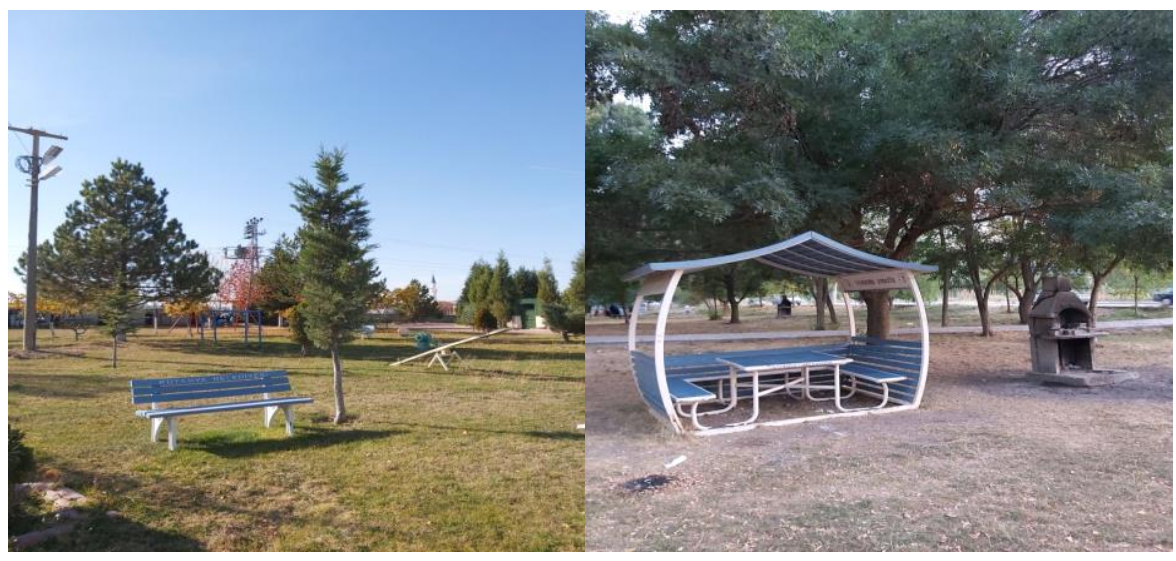

Şekil 7. Çalışma alanının çevresinde bulunan parklardaki oturma elemanları 


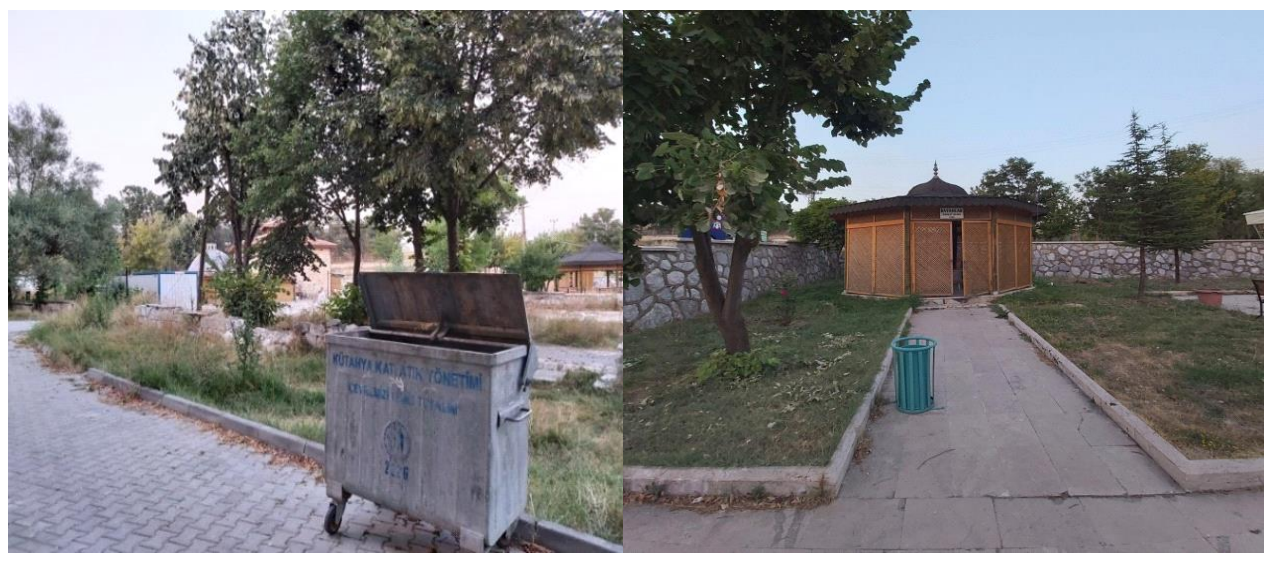

Şekil 8. Çalışma alanının çevresinde bulunan çöp kutuları

Alandaki kentsel mobilyaların, daha estetik bir görünüme kavuşması için ve ilgi odağı haline getirebilmek için toplanma noktası alanlarında (park, piknik alanı, meydan vs.) kentsel mobilya kapasitesi arttırılmalıdır.

Yapılan anketler sonucunda; ziyaretçilerin \%26,7'sinin, alanı çocuklar açısından yeterli derecede güvenilir bulmadığı görüşünde bulunmuştur. Buna bağlı olarak da kontrol noktası ve aydınlatmanın yetersizliğinden kaynaklı sebeplerden gösterilebilir. Alan girişinde ana güzergah boyu sokak aydınlatmasında kullanılan beton aydınlatma direkleri bulunmaktadır. Bazı termal tesis alanlarında farklı metal aydınlatmalar tercih edilmiştir (Şekil 9).

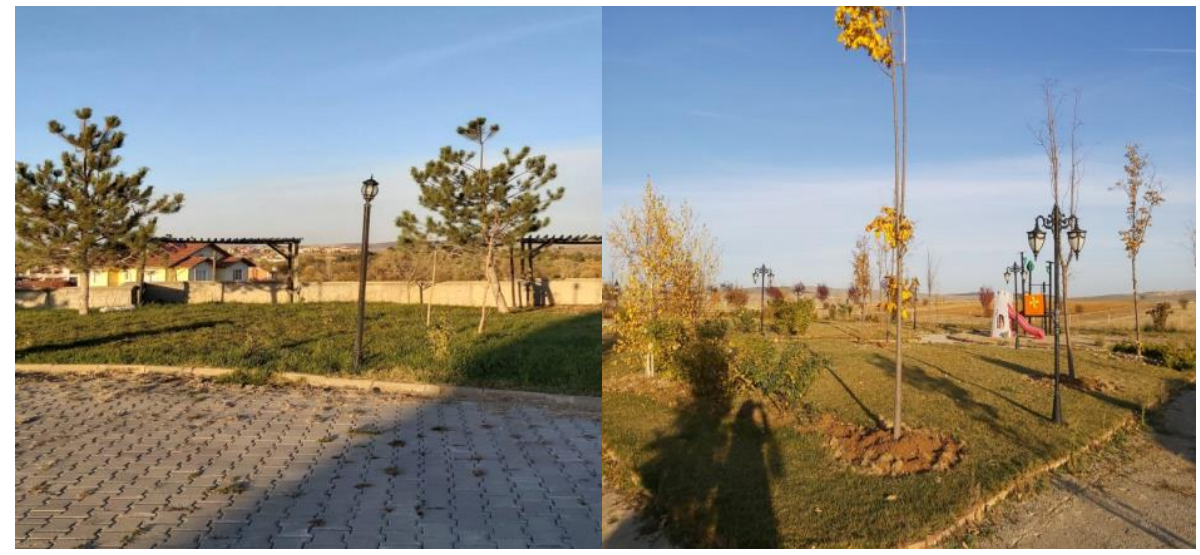

Şekil 9. Çalışma alanındaki termal tesis işletmelerinin bahçelerinde bulunan aydınlatma elemanları

Alanda kullanılan deforme olmuş aydınlatmalar yenilenmeli ve tarihi hamamın çevresinde bulunan alana uyumlu tarihi dokuyla bütünleşen daha estetik ve bütüncül kullanımlar getirilmelidir. Alanın güvenirliliğinin arttırılması için aydınlatmaların belirli mesafelerle kullanımının arttırılması sağlanmalıdır. Alana girişlerde, toplanma alanlarında, tesislerin bahçelerinde vb. yerlerde dikkat çekmeyi arttırabilmek için alanlara uyumlu led ışık, aydınlatma armatürleri, yol ve cadde armatürleri, mantar aydınlatmalar gibi çeşitli aydınlatma elemanları tasarlanmalıdır.

Yapılan anketler sonucunda; ziyaretçilerin \%12,7'sinin yürüyüş yollarının alanda rahatça hareket imkanı sağlamadığı sonucuna ulaşılmıştır (Şekil 10). 


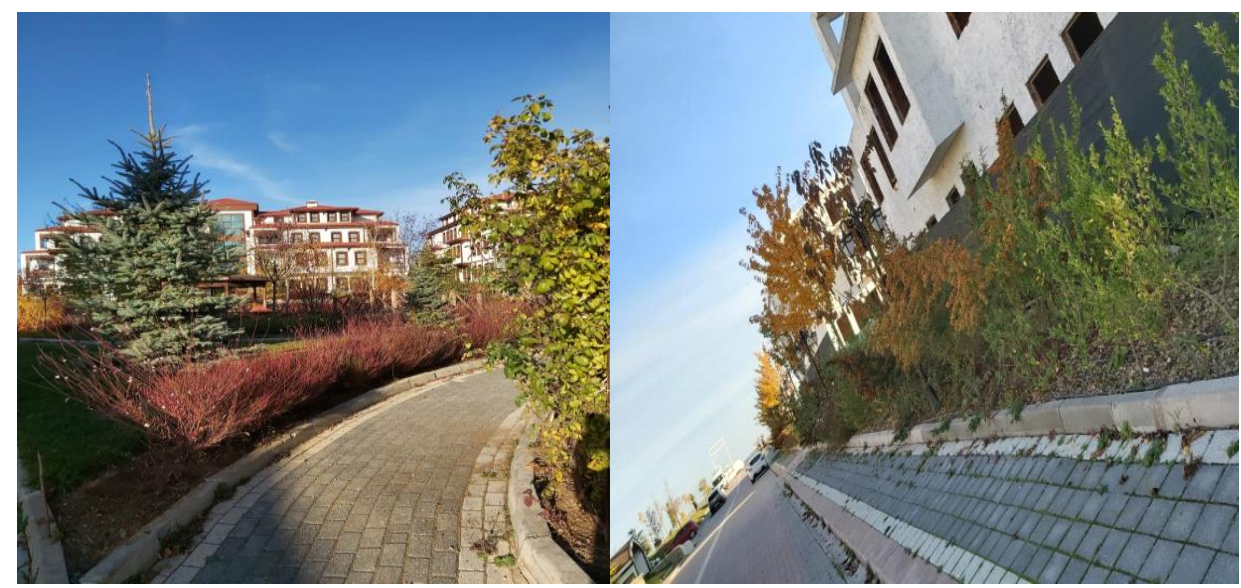

Şekil 10. Çalışma alanındaki termal tesis işletmeleri ve çevresinde kullanılan yürüyüş yolu ve kaldııımlar

Alanda yürüyüş yollarının kullanılabilirliğinin arttııılması için yürüyüş yolları ve kaldırımların genişletilmesi sağlanmalıdır. Alan kullanımlarında Şekil 10'da görüldüğü üzere malzeme yapısı olarak kilit taşı döşeme türüne ağırlık verilmiştir. Alanda yürüyüş yolu olarak bazı termal tesislerin bahçesindeki kullanımlar dışında farklı bağlantı yolları bulunmamaktadır. Bağlantı yolları genellikle yol kenarlarındaki kaldırımlar ile sağlanmaktadır. Alanda farklııkların sağlanması, daha ferah ve ilgi çekici mekanlar oluşturabilmek için alanın yapısına özgü farklı malzemelerle yürüyüş yolu alternatifleri getirilmelidir.

Yapılan anket çalışmaları sonucunda; ziyaretçilerin \%16,7'si, alanın peyzaj açısından yetersiz kaldığı görüşünde bulunmuştur.

Yoncalı Kaplıca tesislerinin bahçesinde veya yakın çevresindeki bitkisel materyaller; Pinus nigra (Karaçam), Picea pungens (mavi ladin), Tilia tomentosa (Ihlamur), Acer palmatum atropurpureum platanoides (kırmızı yapraklı japon akçaağaç), Betula pendula 'Roth' (huş ağacı) vb. ağaç gruplarının olduğu görülmektedir. Buxus sempervirens (şimşir), Rosa (gül), Rosa multiflora (sarmaşık gül), Gaura lindheimeri (uçuşan kelebekler), Juniperus sabina (Sabin ardıcı), Euonymus japonica (taflan), Hibiscus syriacus (hatmi çalısı), Parthenocissus quinquefolia (Amerikan sarmaşığı) vb. çalı ve sarılıcı formlu bitki gruplarının olduğu görülmektedir (Şekil 11).

\section{İşletme Sahiplerine Uygulanan Anket Verilerinin İn- celenmesi}

Ankete katılan işletme sahiplerinin cinsiyet, yaş, eğitim, meslek, gelir durumlarına ait sorular bu başlık altında gösterilmiştir. Buna göre, Ankete katılanların cinsiyet durumlarına bakıldığında; \%83'ünün erkek, \%17'sinin ise kadın olduğu görülmektedir. Ankete katılanların yaş aralıklarına bakıldığında; \%72'sinin 0-65 yaş grubu arasında olduğu, \%25'inin 66-79 yaş grubu arasında olduğu, \%3'ünün 80 ve üzeri yaş grubunda olduğu görülmektedir. Ankete katılanların eğitim durumlarına bakıldığında; \%70'inin ortaöğretim (lise) mezunu, \%13'ünün ön lisans mezunu, \%9'unun ilköğretim mezunu ve \%8'inin lisans mezunu olduğu görülmektedir. Ankete katılanların aylık gelir durumlarına bakıldığında; \%69'unun 399612.375 TL arasında olduğu, \%26'sının 1026-3995 TL arasında olduğu, \%5'inin 12.375 TL üzerinde olduğu sonuçlarına ulaşılmıştır.

Anket çalışmasına katılan işletme sahiplerinin \%89'u işletmelerine ait bir bahçenin olduğunu, $\% 81 ' i$ işletmelerine ait bir bahçenin yeterince bir düzene sahip olmadığını, \%79'u işletmelerine ait bahçenin düzenlemesinin bir peyzaj mimarı tarafından yapılmadığını, \%10'u bir peyzaj mimarı tarafından yapıldığında artışın olduğunu, \%84'ü bahçelerinin bir peyzaj mimarı tarafından tasarlanması gerekli bulduğu, \%16'sı bahçelerinin bir peyzaj mimarı tarafından tasarlanması gerekli bulmadığı sonucuna, \%89'u peyzaj tasarımının masraflı olduğunu ve işletmeye ekstra yük getireceğini, \%88'i işletmelerinde yapılan peyzaj tasarımının işletmelerinin tercih edilmesinde önemli rol oynadığını, \%12'si ise peyzaj tasarımının, işletmelerinin tercih edilmesinde önemli rol oynadığı görüşüne katılmadığı bilgilerine ulaşılmıştır. 


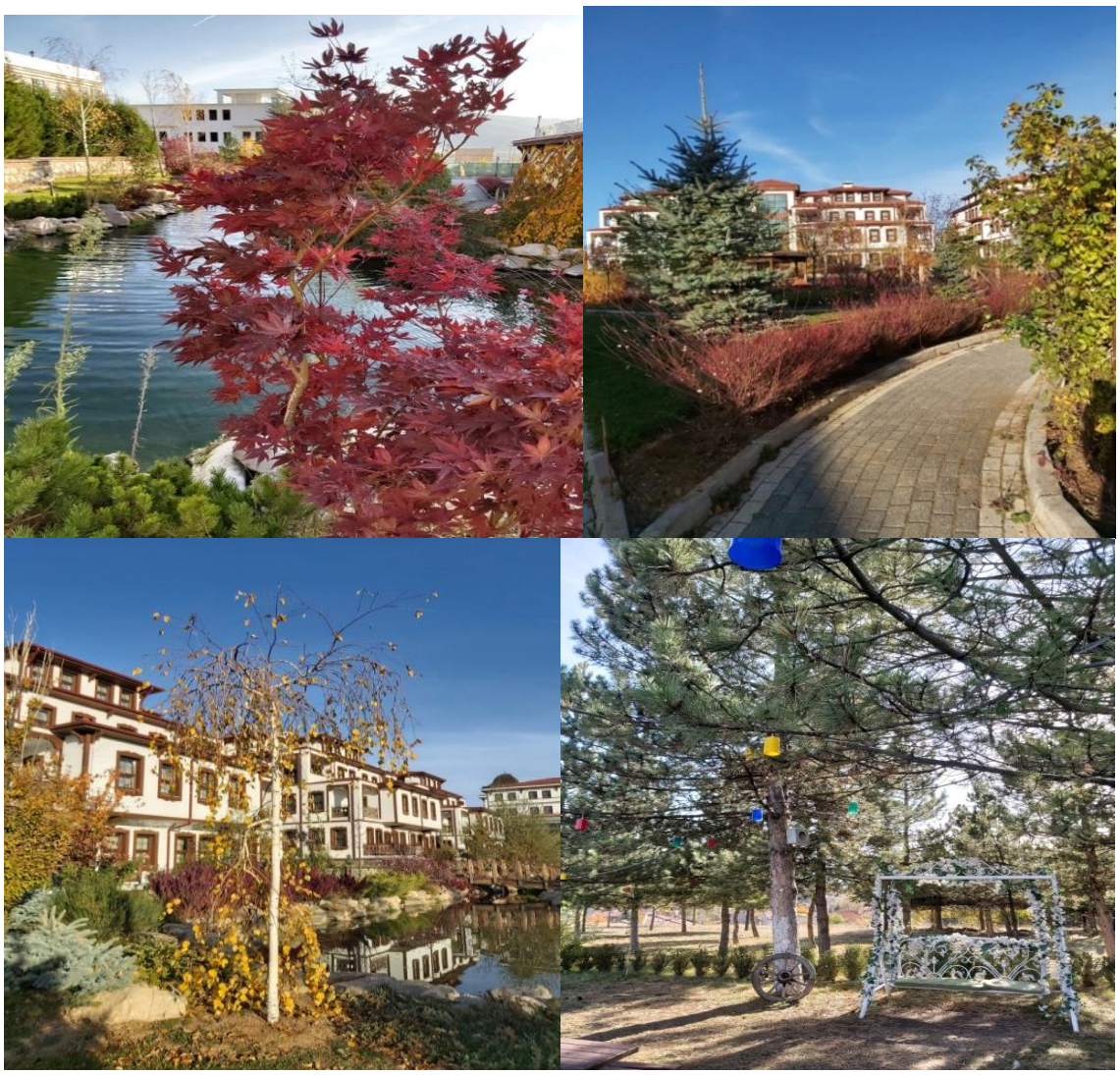

Şekil 11. Çalışma alanındaki termal tesis işletmeleri ve çevresinde kullanılan bitkisel materyaller

\section{Ki-Kare Testi İle Yapılan Karşılaştırma Sonuçları}

Yoncalı termal tesis alanını gelen ziyaretçiler ve tesis alanında bulunan işletme sahiplerine uygulanan anket sonuçlarına bakıldığında, değişkenler (anket formundaki sorulara verilen cevaplar) arasında istatistiki açıdan ilişkisinin değerlendirilmesine "ki-kare testi" uygulanarak bakılmıştır. Yapılan anket verilerinin ki-kare testi analizleri için anlamlı fark değerlendirilmeleri aşağıda verilmiştir;

- Yapılan $X^{2}$ analizleri doğrultusunda ziyaretçilerin, "Hangi bölgeden geliyorsunuz?" sorusunun demografik verilerle anlamlı farkı incelendiğinde; yaş aralığı $(p=0,00)$, meslek $(p=0,00)$, aylık gelir durumu $(p=0,038)$ değişkenleri ile anlamlı fark olduğu, cinsiyet $(p=0,252)$ ve eğitim durumu $(p=0,147)$ değişkenleri ile anlamlı fark olmadığı tespit edilmiştir. Yaş araığı, meslek ve aylık gelir durumu değişkenlerinin; hangi bölgeden geldiklerinde etkili olduğu sonucuna ulaşılmıştır.

- Yapılan $X^{2}$ analizleri doğrultusunda ziyaretçilerin, "Yoncalı'daki termal tesislere geliş sıklığınız nedir?" sorusunun demografik verilerle anlamlı farkı incelendiğinde; cinsiyet $(p=0,00)$, yaş aralığı $(p=0,00)$, eğitim durumu $(p=0,00)$, meslek $(p=0,00)$, aylık gelir durumu $(p=0,00)$ değişkenleri ile anlamlı fark olduğu tespit edilmiştir. Tüm değişkenlerin; tesislere geliş sıklığını etkilediği sonucuna ulaşılmıştır.

- Yapılan $X^{2}$ analizleri doğrultusunda ziyaretçilerin, "Yoncalı'daki termal tesislere ulaşım şekliniz genellikle nedir?" sorusunun demografik verilerle anlamlı farkı incelendiğinde; yaş aralığı $(p=0,00)$, meslek $(p=0,00)$, aylık gelir durumu $(p=0,00)$ değişkenleri ile anlamlı fark olduğu, cinsiyet $(p=0,106)$ ve eğitim durumu $(p=0,074)$ değişkenleri ile anlamlı fark olmadığı tespit edilmiştir. Yaş aralığı, meslek ve aylık gelir durumu değişkenlerinin; ulaşım şeklinde etkili olduğu sonucuna ulaşılmıştır.

- Yapılan $X^{2}$ analizleri doğrultusunda ziyaretçilerin, "Alana genellikle kimlerle geliyorsunuz?" sorusunun demografik verilerle anlamlı farkı incelendiğinde; cinsiyet $(p=0,026)$, yaş aralığı $(p=0,00)$, meslek $(p=0,00)$, aylık gelir durumu $(p=0,00)$ değişkenleri ile anlamlı fark olduğu, eğitim durumu $(p=0,279)$ değiş- 
keni ile anlamlı fark olmadığı tespit edilmiştir. Cinsiyet, yaş aralığı, meslek ve aylık gelir durumu değişkenlerinin; alana nasıl gelindiğinde etkili olduğu sonucuna ulaşılmıştır.

- Yapılan $X^{2}$ analizleri doğrultusunda ziyaretçilerin, 'Yoncalı'daki termal tesislerde cezbedici bulduğunuz özellikler nelerdir?" sorusunun demografik verilerle anlamlı farkı incelendiğinde; yaş aralığı $(p=0,00)$, eğitim durumu $(p=0,00)$, meslek $(p=0,00)$, aylık gelir durumu $(p=0,00)$ değişkenleri ile anlamlı fark olduğu, cinsiyet $(p=0,545)$ değişkeni ile anlamlı fark olmadığı tespit edilmiştir. Yaş aralığı, eğitim durumu, meslek ve aylık gelir durumu değişkenlerinin; tesislerde cezbedici özellikleri bulmada etkili olduğu sonucuna ulaşılmıştır.

- Yapılan $X^{2}$ analizleri doğrultusunda ziyaretçilerin, 'Yoncalı'daki termal tesislerin sevmediğiniz veya sizi rahatsız eden yönleri nelerdir?" sorusunun demografik verilerle anlamlı farkı incelendiğinde; yaş aralığı $(p=0,00)$, eğitim durumu $(p=0,00)$, meslek $(p=0,00)$ değişkenleri ile anlamlı fark olduğu, cinsiyet $(p=0,461)$ ve aylık gelir durumu $(p=0,111)$ değişkenleri ile anlamlı fark olmadığı tespit edilmiştir. Yaş araığı, eğitim durumu ve meslek değişkenlerinin; tesislerde rahatsız edici özellikleri bulmada etkili olduğu sonucuna ulaşılmıştır.

- Yapılan $X^{2}$ analizleri doğrultusunda ziyaretçilerin, 'Tesisi seçerken peyzaj tasarımının olup olmamasına dikkat eder misiniz?" sorusunun demografik verilerle anlamlı farkı incelendiğinde; yaş aralığı $(p=0,006)$, eğitim durumu $(p=0,00)$, meslek $(p=0,00)$ değişkenleri ile anlamlı fark olduğu, cinsiyet $(p=0,956)$ ve aylık gelir durumu $(p=0,099)$ değişkenleri ile anlamlı fark olmadığı tespit edilmiştir. Yaş araığı, eğitim durumu ve meslek değişkenlerinin; tesislerde peyzaj tasarımının fark oluşturmada etkili olduğu sonucuna ulaşılmıştır.

- Yapılan $X^{2}$ analizleri doğrultusunda ziyaretçilerin, "Peyzaj tasarımının işletmelere maddi ve manevi katkı sağladığını ve ziyaretçilerde olumlu etkiler bıraktığını düşünüyor musunuz?" sorusunun demografik verilerle anlamlı farkı incelendiğinde; eğitim durumu $(p=0,00)$ ve meslek $(p=0,00)$ değişkenleri ile anlamlı fark olduğu, cinsiyet $(p=0,908)$, yaş aralığı $(p=0,908)$ ve aylık gelir durumu $(p=0,590)$ değişkenleri ile anlamlı fark olmadığı tespit edilmiştir. Eğitim durumu ve meslek değişkenlerinin; peyzaj tasarımı yapılan işletmelere katkılarının olmasında etkili olduğu sonucuna ulaşılmıştır.
- Yapılan $X^{2}$ analizleri doğrultusunda işletme sahiplerinin, "Işletmenize ait bir bahçe bulunuyor mu?" sorusunun demografik verilerle anlamlı farkı incelendiğinde; yaş aralığı $(p=0,00)$ ve aylık gelir durumu $(p=0,00)$ değişkenleri ile anlamlı fark olduğu, cinsiyet $(p=0,912)$ ve eğitim durumu $(p=0,344)$ değişkenleri ile anlamlı fark olmadığı tespit edilmiştir. Yaş aralığı ve aylık gelir durumu değişkenlerinin; işletmelerde bahçe bulundurmada etkili olduğu sonucuna ulaşılmıştır.

- Yapılan $X^{2}$ analizleri doğrultusunda işletme sahiplerinin, "İşletmenize ait bahçenin gereksinimleri doğrultusunda eksiksiz düzenlenmiş olduğunu düşünüyor musunuz?" sorusunun demografik verilerle anlamlı farkı incelendiğinde; yaş $(p=0,00)$, eğitim durumu $(p=0,00)$ ve aylık gelir durumu $(p=0,00)$ değişkenleri ile anlamlı fark olduğu, cinsiyet $(p=0,937)$ değişkeni ile anlamlı fark olmadığı tespit edilmiştir. Yaş, eğitim durumu ve aylık gelir durumu değişkenlerinin; bahçenin gereksinimlerine göre tasarlanmasında etkili olduğu sonucuna ulaşılmıştır.

- Yapılan $X^{2}$ analizleri doğrultusunda işletme sahiplerinin, "İ̧̧letmenize ait bahçenin tasarlanması bir peyzaj mimarı tarafından yapıldı mı?" sorusunun demografik verilerle anlamlı farkı incelendiğinde; yaş $(p=0,00)$ ve aylık gelir durumu $(p=0,00)$ değişkenleri ile anlamlı fark olduğu, cinsiyet $(p=0,824)$ ve eğitim durumu $(p=0,140)$ değişkenleri ile anlamlı fark olmadığı tespit edilmiştir. Yaş ve aylık gelir durumu değişkenlerinin; işletmelerdeki bahçelerin tasarımlarının bir peyzaj mimarı tarafından yapılmasında etkili olduğu sonucuna ulaşılmıştır.

- Yapılan $x^{2}$ analizleri doğrultusunda işletme sahiplerinin, "İşletmenize ait bahçenin tasarımı bir peyzaj mimarı tarafından yapıldıysa ziyaretçi açısından artış olduğunu gözlemliyor musunuz?" sorusunun demografik verilerle anlamlı farkı incelendiğinde; yaş $(p=0,00)$ ve aylık gelir durumu $(p=0,00)$ değişkenleri ile anlamlı fark olduğu, cinsiyet $(p=0,824)$ ve eğitim durumu $(p=0,140)$ değişkenleri ile anlamlı fark olmadığı tespit edilmiştir. Yaş ve aylık gelir durumu değişkenlerinin; işletmelere ait bahçelerin peyzaj mimarları tarafından tasarlandığında artış olmasında etkili olduğu sonucuna ulaşılmıştır.

- Yapılan $x^{2}$ analizleri doğrultusunda işletme sahiplerinin, "İ̧̧letmenize ait bahçenin tasarımının bir peyzaj mimarı tarafından yapılması gerektiğini düşünüyor musunuz? (İşletmenize ait bahçe yoksa olduğunda nasıl değerlendirirsiniz?)" sorusunun demografik verilerle anlamlı farkı incelendiğinde; yaş $(p=0,00)$, eğitim durumu $(p=0,00)$ ve aylık gelir durumu $(p=0,00)$ 
değişkenleri ile anlamlı fark olduğu, cinsiyet $(p=0,353)$ değişkeni ile anlamlı fark olmadığı tespit edilmiştir. Yaş, eğitim durumu ve aylık gelir durumu değişkenlerinin; peyzaj tasarımının peyzaj mimarlarının planlama ve tasarımlarıyla şekillenmesi gerekliliğini göstermede etkili olduğu sonucuna ulaşılmıştır.

- Yapılan $X^{2}$ analizleri doğrultusunda işletme sahiplerinin, "İ̧̧letmenize ait bahçenin tasarımının işletmeye ekstra yük getireceğini ve masraflı olduğunu düşünüyor musunuz? (İşletmenize ait bahçe yoksa, olduğunda nasıl değerlendirirsiniz?) sorusunun demografik verilerle anlamlı farkı incelendiğinde; aylık gelir durumu $(p=0,00)$ değişkeni ile anlamlı fark olduğu, cinsiyet $(p=0,912)$, yaş $(p=0,227)$, eğitim durumu $(p=0,951)$ değişkenleri ile anlamlı fark olmadığı tespit edilmiştir. Aylık gelir durumu değişkeninin; peyzaj tasarımın masraflı olduğunu göstermede etkili olduğu sonucuna ulaşılmıştır.

Yapılan $X^{2}$ analizleri doğrultusunda işletme sahiplerinin, "İşletmenizin tercih edilmesinin nedenleri arasında peyzaj tasarımının önemli bir rol oynadığını düşünüyor musunuz? (İşletmenize ait bahçe yoksa olduğunda nasıl değerlendirirsiniz?)" sorusunun demografik verilerle anlamlı farkı incelendiğinde; yaş $(p=0,016)$ ve aylık gelir durumu $(p=0,00)$ değişkenleri ile anlamlı fark olduğu, cinsiyet $(p=0,432)$ ve eğitim durumu $(p=0,069)$ değişkenleri ile anlamlı fark olmadığı tespit edilmiştir. Yaş ve aylık gelir durumu değişkenlerinin; peyzaj tasarımı yapılan tesislerdeki işletmeleri daha çok tercih etmesinde etkili olduğu sonucuna ulaşılmıştır.

\section{SONUÇLAR}

Kaplıca turizmi dört mevsim tercih edilen bir sağlık turizmi olduğu için önemi gün geçtikçe artmaktadır. Hem sağlık hem de rekreasyona olanak sağladığı için ayrıca gelişim göstermektedir. Kaplıca turizmi; yeni kültürlerden insanları tanıma ve kaynaşma, doğal ortamda bulunarak ruhsal sorunları tedavi etme, stresi atma, yapılan kürler, fizik tedavi ve farklı uygulama metotlarıyla tedaviye erken cevap verme gibi birçok olumlu yönleriyle çeşitlilik sağlamaktadır.

Alanda bitkisel materyal çeşitliliği arttırılmalı ve işlevine uygun bitki türleri dikilerek mekanın ekolojik ve görsel kalitesi arttırılmalıdır. Sosyokültürel açıdan Alaaddin Keykubat Tarihi Hamamı'nın çevresine bakıldığında herhangi bir peyzaj çalışması bulunmaması ve çok bakımsız olması dolayısıyla işletmenin olumsuz etkilenmemesi ve tarihi alanın değer kazanabilmesi için alanında uzman peyzaj mimarları tarafından işlevine uygun bitkilerle ve alana uygun objelerle gerekli görüşler alındıktan sonra peyzaj planlama ve tasarım çalışmaları yapılmalıdır. İşletme bahçesinde ve yakın çevresinde bulunan bitkilerin bakım çalışmaları düzenli periyotlarla yapılıp (çapalama, gübreleme, sulama, budama, çim biçimi vb.) gerekli özenin gösterilmesi sağlanmalıdır.

Termal tesislerin bahçesinde bitkilerle oluşturulacak labirentler, dikey bahçeler, kaya bahçeleri, bitkileri tanımayı sağlayan bitki adaları vb. özel alanlar oluşturulabilir. İlgi çekiciliği arttırabilmek için, bitkisel materyallerle oluşturulacak fotoğraf çekim alanları tasarlanabilir. Kapııaya gelen ziyaretçilerde güzel bir anı oluşturabilmek ve geleceğe yönelik katkılarda bulunabilmek için, kapIıca tesislerindeki işletmeciler tarafından oluşturulacak farklı bir yöntemle; (ağaç dikme çalışmaları ile kaplıca indirimlerinden faydalanılması vs.) farklı türlerdeki ağaç çeşitlerini uygun bölgelerde anı bahçesi adında özel alanlar oluşturarak "Geleceğe Bir Anı'da Sen Bırak" sloganı ile hem bitkisel çeşitlilik anlamında geleceğe yönelik büyük katkılar sağlanabilir hem de ziyaretçiler açısından farklı bir ambiyans oluşturup turizme büyük katkılar sağlanarak, ekonomiye canlılık getirilebilir.

Sonuç olarak, kaplıca turizmi dört mevsim tercih edilmesi sayesinde büyük kazanımları olan bir turizm türüdür. Ülkemizde de önemli termal tesis merkezleri bulunmaktadır. Anket sonuçlarından da çıkarılacağı üzere; tesislerin tercih edilebilirliğinin arttırılması ve turizme yönelik katkılar sağlayabilmek için, çevresinde yapılacak planlama ve tasarım çalışmalarının işlevine uygun olarak alanında uzmanlaşmış peyzaj mimarları tarafından yapılmasının bir gereklilik olduğu unutulmamalıdır.

\section{TEŞEKKÜR}

Bu çalışma, Prof. Dr. Mehmet TOPAY'ın danışmanlığında Rumeysa KANBER tarafından hazırlanan yüksek lisans tezinin verileri kullanılarak hazırlanmıştır.

\section{KAYNAKLAR}

Climate-Data (2019). Yoncalı İklim. https://tr.climatedata.org/asya/tuerkiye/kuetahya/yoncal\%C4\%B1-671520/ (Erişim Tarihi: 23.12.2019)

Deniz, M. (2016). Termal Turizm Açısından Kayaağil Termal Tesisleri (Uşak). Tarih Okulu Dergisi, 9(25):311-349.

Devecioğlu, N. E. (2015). Troya Ören Yeri Peyzaj Düzenlemelerinin İrdelenmesi ve Geliştirilmesi Üzerine Bir Araştırma. Yüksek Lisans Tezi. Süleyman Demirel Üniversitesi, Fen Bilimleri Enstitüsü, Peyzaj Mimarlığı Anabilim Dalı, Isparta.

Haşimoğlu, A. (2007). Yoncalı (Kütahya) Kaplıcasının Bugünkü Konumu ve Geleceği. Türk Mühendis ve Mimar Odaları Birliği Jeotermal Kongresi, Ankara. 
Kök, M. (2013). Sağlık Turizmi Açısından Termal Turizm (Denizli Örneği), Beykent Üniversitesi, Sosyal Bilimler Enstitüsü, İşletme Yönetimi Ana Bilim Dalı, Yüksek Lisans Tezi, $101 \mathrm{~s}$, İstanbul.

KTB (2020). Kültür ve Turizm Bakanlığı. İşletme (Bakanlık) Belgeli Tesis Konaklama İstatistikleri. https://yigm.ktb.gov.tr/TR-201121/isletme-bakanlik-belgelitesis-konaklama-istatistikleri.html (Erişim Tarihi: 13.10.2020)

Topay, M., Küçük, V. (2010). Termal ve Maden Suları Tesislerinde Peyzaj Tasarımının Önemi. Bartın Orman Fakültesi Dergisi, 12(17): 83-91.
Uzun, S., Müderrisoğlu, H., Yıldız, O., Çakır, G., Aksoy, N., Kaya, L.G., Demir, Z., Aşıkkutlu H.S. (2013). Doğal Alanlardaki Farklı Rekreasyonel Faaliyetlerin Ekolojik Etkileri. II. Rekreasyon Araştırmaları Kongresi Bildiriler Kitabı, 101128, Kuşadası-Aydın.

Vural, H. (2019). Bingöl Ilıcalar Beldesi ve Yakın Çevresinin Peyzaj Özellikleri ve Kirsal Turizm Potansiyeli. Bingöl Üniversitesi Sosyal Bilimler Enstitüsü Dergisi, 9(9): 381-410.

Yandex (2020). https://yandex.com.tr/harita/103839/kutahya/geo/yoncali_mah/ (Erişim Tarihi:10.08.2020) 